\title{
PRODUCTION OF A BIOPESTICIDE BASED ON A CYSTEINE PROTEASE ENZYME FROM LATEX AND PAPAYA (CARICA PAPAYA) FOR SPODOPTERA LITURA IN RED CHILI PEPPERS (CAPSICUM ANNUUM)
}

\author{
Anondho Wijanarko ${ }^{1}$, Danti Firda Nur ${ }^{1}$, Muhamad Sahlan ${ }^{1}$, Nadia Tuada Afnan ${ }^{1}$, \\ Tania Surya Utami ${ }^{1}$, Heri Hermansyah ${ }^{2 *}$ \\ ${ }^{1}$ Department of Chemical Engineering, Faculty of Engineering, Universitas Indonesia, Kampus UI \\ Depok, Depok 16424, Indonesia \\ ${ }^{2}$ Directorate Research and Community Services (DRPM) Universitas Indonesia, Kampus UI Depok, \\ Depok 16424, Indonesia
}

(Received: January 2017 / Revised: May 2017 / Accepted: October 2017)

\begin{abstract}
Spodoptera litura is one of the major pests on red chili peppers (Capsicum annuum). Larvae damage crops by biting, chewing, and then eating the lower surface of the leaves. The leaves became transparent white, and severe damage only leaves the leaf's midrib and veins. Papaya latex (Carica papaya) could be used as a pesticide because it contains cysteine protease, which is a substance that can inhibit the insects from eating the leaves or even kill the pests. The purpose of this study was to produce an organic pesticide from the cysteine protease extracted from papaya latex that is effective against Spodoptera litura. A completely randomized design was used with latex from papaya leaves, papaya rind, and papaya fruit. The methods used were blending and tapping. The blending method was conducted via a chemical extraction using buffer phosphate and ammonium sulfate. The tapping method was conducted via a chemical extraction using acetone. These methods were compared by using an enzyme activity test and efficacy test. The enzyme activity test used a UV-Vis spectrophotometer and the efficacy test was done on Spodoptera litura larvae, which were given red chili pepper leaf covered with an organic pesticide from cysteine protease.
\end{abstract}

Keywords: Cysteine protease; Papaya latex; Red chili pepper; Spodoptera litura

\section{INTRODUCTION}

Horticultural crops, such as peppers and tomatoes, are some of the many vegetables that have been developed as commodities as they are some of the basic foods needed. These plants can be planted in high-temperature areas, in the low plains, or in land that is dry, even in former rice fields. According to a report from the Directorate General of Horticulture (Taufik, 2015), the capsicum harvest of Indonesia in 2015 was from 120,847 hectares and had a total production of $1,045,182$ tons, with an average yield of 8.65 tons per year. This value is still much lower than for the crops produced in other countries, such as the United States and China, among others. It is caused by the presence of impaired organism bullies (IOBs) of plants that can derail the red chili crop. One of the many IOBs that attacks capsicums is the Spodoptera litura. Spodoptera litura, the Oriental leafworm moth, is a noctuid moth which is considered to be an agricultural pest. It is also known as the cluster caterpillar, cotton leafworm, tobacco cutworm, or tropical armyworm. Armyworms are the main object of this research because of their fast lifecycle, they *Corresponding author's email: heri.hermansyah@ui.ac.id, Tel: +62-813-8539-9048, Fax: +62-21-7863515
Permalink/DOl: https://doi.org/10.14716/ijtech.v8i8.788 
are polyphagous, and they breed easily (Mursyahadah et al., 2015). They are found in the IndoAustralian tropics, and they are also established on most Polynesian islands, where they occurs in a variety of island forms. The stricken plants are characterized by the presence of leaves that have been eaten to the extent that only the leaves' midribs and veins are left behind. One way to eradicate grubs is by using pesticides.

Pesticides are chemical substances used to kill or control a range of pests (Djojosumarto, 2008). Organic pesticides are pesticides derived from plants, to control the population of the optimum population trust (OPT) (Syakir et al., 2012). Organic pesticides are readily degraded in nature (biodegradable), so there is no significant residue from organic pesticides on the plant and or in the environment. One of the active ingredients that is widely used in a biopesticide is cysteine protease. A protease or peptidase, also known as a proteinase, is an enzyme that will break down the protein-a molecule into something that is simpler, such as short or oligopeptide amino acids, through the hydrolysis reaction of peptides in bonding (Bauer et al., 1996). Protease has the potential to be a pesticide, due to the activity of proteolytic enzymes. The proteolytic activity of enzymes can damage tissue and protein is important for insects. A protease derived from plants can invade insect herbivores. Proteases are instrumental in the spread of microbial pathogens that are highly pathogenic to the cells of the insect. Proteases are also found in the venom of the arthropods that are predators of insects. In addition, the microbial pathogens that are present in the body of the insect will experience a growth spurt.

\section{METHODOLOGY}

\subsection{Materials}

This research was conducted at the Bioprocess Laboratory, Chemical Engineering Department, Engineering Faculty, Universitas Indonesia, Depok. The rind, leaves, and fruit of the papaya that were used in this research were aged for 2-3 days. The Spodoptera litura were purchased from Bogor Agricultural University, and the tyrosine, casein, and trichloroacetic acid (TCA) (technical grade) were purchased from PT Pasifik Kimia, Indonesia.

\subsection{Extraction using the Blending Method}

The papaya fruit, leaf, and rind were sliced into small pieces, and a phosphate buffer ( $\mathrm{pH} 7)$, and $0.1 \%$ solution $\mathrm{b} / \mathrm{v} \mathrm{NaCl}$ and $\mathrm{NaHSO}_{3}$ (1:1) were added into each sample. The extraction process was continued by blending and filtering with nylon filter steps. The samples were then centrifuged at $4,000 \mathrm{rpm}$ for 30 minutes and precipitated with ammonium sulfate $60 \%$. The filtered juice was then deposited for 24 hours. The samples were then centrifuged for a second time at $1,000 \mathrm{rpm}$ for 10 minutes, and lastly were filtered with a nylon filter to remove any impurities.

\subsection{Extraction using the Tapping Method}

An amount of $4 \mathrm{~g}$ of papaya latex from rind was dissolved in $40 \mathrm{~mL}$ of $0.1 \mathrm{M}$ phosphate buffer solution ( $\mathrm{pH} 7$ ). The mixture was left for 2 hours at $4^{\circ} \mathrm{C}$, then centrifuged at $4,000 \mathrm{rpm}$ for 15 minutes. The filtrate was obtained using a precipitation process with $50 \%$ acetone, and the filtrate was centrifuged at 1,000 rpm for 10 minutes. Last, the solution was filtered with a nylon filter to remove any impurities.

\subsection{Enzymatic Activity Determination}

The definition of protease activity is the production of $1 \mu \mathrm{g}$ tyrosine by hydrolyzing casein at a certain temperature. The following steps were used to determine protease activity. Both $2 \mathrm{ml}$ of crude extract and $2 \mathrm{ml}$ phosphate buffer $(\mathrm{pH} \mathrm{7})$ were mixed and then the solution was incubated for 5 minutes at $37^{\circ} \mathrm{C}$. Next, $2 \mathrm{ml}$ of $2 \%$ casein was added to $2 \mathrm{ml}$ phosphate buffer $0.05 \mathrm{M}$ (pH 7 ), then the solution was incubated for 10 minutes at $37^{\circ} \mathrm{C}$. The assay was stopped by adding 4 $\mathrm{ml}$ of $0.4 \mathrm{M}$ TCA (Qiao et al., 2009). The color reaction was observed by pouring $2 \mathrm{ml}$ of the 
extracted casein-TCA solution with $6 \mathrm{ml}$ of biuret and $0.3 \mathrm{ml}$ of Folin-Ciocalteu reagent. Then, the solution for a control group was used to adjust the extinction, and the absorbance at $750 \mathrm{~nm}$ was measured. The absorbances were compared with the free tyrosine standard curve, which was created by checking the absorbance of free tyrosine at 20, 40,60, 80, and $100 \mathrm{ppm}$. The formula of protease activity calculation is as follows:

$$
C_{t}=\frac{A_{t}}{A_{s t d}} \times C_{s t d}
$$

where $C_{t}$ is the concentration of free tyrosine in crude extract (ppm), $C_{s t d}$ is the concentration of free tyrosine in standard curve $(\mathrm{ppm}), A_{t}$ is the crude enzyme absorbance, and $A_{\text {std }}$ is the tyrosine standard absorbance.

\subsection{Odor and Lifetime Test}

Odor and lifetime tests were conducted to observe if there were any physical changes during the storage time and specified conditions. The odor test was done every day for a week, while the lifetime test was done on the $7^{\text {th }}$ and $14^{\text {th }}$ days. Crude extracts were placed in different temperature storage areas (at $10^{\circ} \mathrm{C}, 27^{\circ} \mathrm{C}$, and $37^{\circ} \mathrm{C}$ ) and observed for their smell.

\subsection{Efficacy Test}

The efficacy test was the major test used in this research, which observed the correlation between dipped leaves and the leaves remaining uneaten. The test was conducted by dipping three leaves into each variation of the crude extract plus a negative control. Each day for seven days, the leaves were observed.

\section{RESULTS AND DISCUSSION}

\subsection{Protease Activity Assay}

The protease activity is provided in Table 1 and given as a visual representation in Figure 1 for a better comparison. The result shows the rind of papaya extract has the highest enzyme activity.

Table 1 Protease activity

\begin{tabular}{clc}
\hline No. & Source & Protease Activity $(\mathrm{ppm})$ \\
\hline 1. & Leaf & 21.69 \\
2. & Fruit & 26.44 \\
3. & Rind & 98.11 \\
4. & Tapped Rind & 77.13 \\
\hline
\end{tabular}

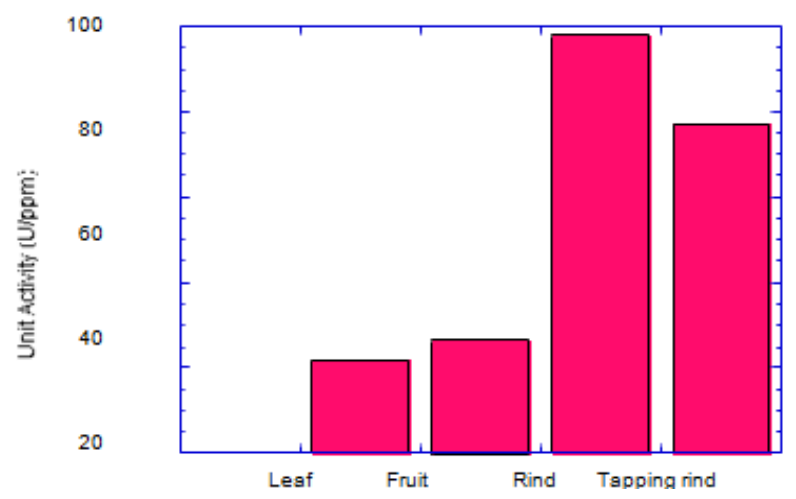

Figure 1 Protease Activity 
It is because the rind of the papaya produces more latex than any other part of the papaya, such as the leaves or fruit. Therefore, its protease content is much higher as well. Various methods of extraction were conducted in this research to find the best way to obtain the rind's papaya latex; those methods were tapping and blending.

The latex extracted from the papaya rind using the blending method has a higher activity than latex extracted from the rind with the tapping method. From the previously data, we can assume the tapping method is harsher and less controlled than the blending method. On the other hand, the tapping method caused a decrease in enzyme activity compared to the blending method.

\subsection{Odor Test}

The odor test is a qualitative test, which was measured subjectively by the author's nose. Parameters were used so that the qualitative data could be quantified. The parameters and scoring are as follows.

Table 2 Parameters for the odor test

\begin{tabular}{ccl}
\hline No. & Value & \multicolumn{1}{c}{ Smell Parameters } \\
\hline 1. & 5 & Fresh and Strong \\
2. & 4 & Fresh, less strong \\
3. & 3 & Fresh \\
4. & 2 & Acidic \\
5. & 1 & Highly acidic \\
\hline
\end{tabular}

The results of the odor test is shown in Tables 3 to 5. Based on the data in these tables, we can conclude that the protease obtained using the blending method has a less fresh odor than protease from the tapping method. The odor of the protease extracted using the tapping method is caused by the oxidation reaction that occurred when the latex was tapped from the tree. The crude extracts that were stored at $27^{\circ} \mathrm{C}$ and $37^{\circ} \mathrm{C}$ only lasted for two days before their smell and color got worse. The changes in smell identified through this test indicate the denaturation process occurring in each extract. The odor of the extracts stored at $10^{\circ} \mathrm{C}$ lasted for seven days in general.

Table 3 Odor test at a storage temperature of $10^{\circ} \mathrm{C}$

\begin{tabular}{llllllll}
\hline \multirow{2}{*}{ Sample } & \multicolumn{7}{c}{ Day } \\
\cline { 2 - 8 } \multicolumn{1}{c}{} & 1 & 2 & 3 & 4 & 5 & 6 & 7 \\
\hline Leaf & 5 & 5 & 5 & 5 & 5 & 5 & 5 \\
Fruit & 5 & 5 & 5 & 5 & 5 & 5 & 5 \\
Rind & 5 & 5 & 5 & 5 & 5 & 5 & 5 \\
Tapping Rind & 5 & 4 & 4 & 4 & 3 & 3 & 3 \\
\hline
\end{tabular}

Table 4 Odor test in at a storage temperature of $27^{\circ} \mathrm{C}$

\begin{tabular}{llllllll}
\hline \multirow{2}{*}{ Sample } & \multicolumn{7}{c}{ Day } \\
\cline { 2 - 8 } & 1 & 2 & 3 & 4 & 5 & 6 & 7 \\
\hline Leaf & 5 & 5 & 4 & 4 & 4 & 4 & 4 \\
Fruit & 5 & 5 & 4 & 4 & 4 & 4 & 4 \\
Rind & 5 & 5 & 5 & 5 & 5 & 5 & 5 \\
Tapping Rind & 4 & 4 & 4 & 4 & 3 & 3 & 3 \\
\hline
\end{tabular}


Table 5 Odor test at a storage temperature of $37^{\circ} \mathrm{C}$

\begin{tabular}{llllllll}
\hline \multirow{2}{*}{ Sample } & \multicolumn{7}{c}{ Day } \\
\cline { 2 - 8 } & 1 & 2 & 3 & 4 & 5 & 6 & 7 \\
\hline Leaf & 5 & 5 & 4 & 4 & 4 & 4 & 4 \\
Fruit & 5 & 5 & 4 & 4 & 4 & 4 & 4 \\
Rind & 5 & 5 & 4 & 4 & 4 & 4 & 4 \\
Tapping Rind & 4 & 4 & 4 & 4 & 3 & 3 & 3 \\
\hline
\end{tabular}

\subsection{Lifetime Test}

The lifetime test was conducted to determine the lifetime of the crude papain extract. The data was obtained on the $7^{\text {th }}$ and $14^{\text {th }}$ days of the test. The results of the lifetime test are revealed in Figures $2 \mathrm{a}, 2 \mathrm{~b}$, and $2 \mathrm{c}$. From the test, the crude papain with the longest lifetime the one stored at $10^{\circ} \mathrm{C}$. However, the optimum condition for enzymes is at a temperature of $37^{\circ} \mathrm{C}$ because there was a decrement in enzymatic activity when stored at temperatures of $10^{\circ} \mathrm{C}$ and $27^{\circ} \mathrm{C}$.

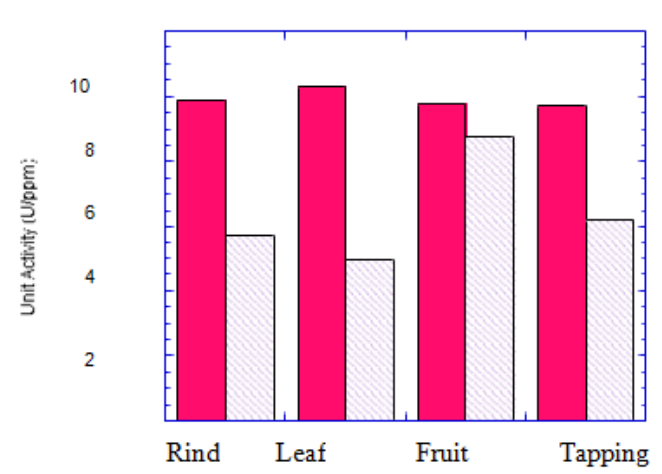

(a)

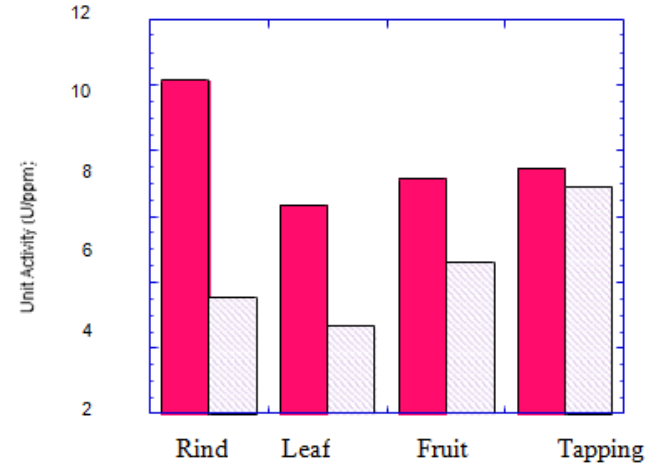

(b)

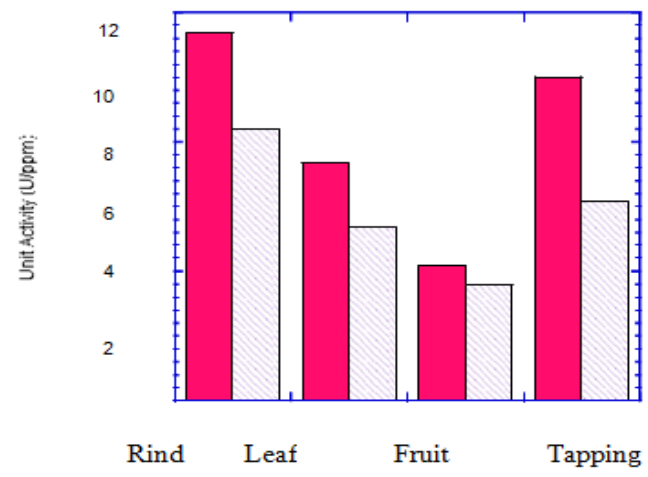

(c)

Figure 2 Lifetime test in storage temperature of: (a) $10^{\circ} \mathrm{C}$; (b) $27^{\circ} \mathrm{C}$; and (c) $37^{\circ} \mathrm{C}$

\subsection{Efficacy Test}

The results of the efficacy test are given in Table 6. Based on the observations made, leaves that were dipped into various sources of crude papain extract were eaten by the Spodoptera litura with $100 \%$ mortality. This indicates that crude papain extract is powerful enough to kill third and fourth instar Spodoptera litura, especially when the leaves are in a wet condition and the skin of the Spodoptera litura was exposed to the extract. 
Table 6 Efficacy test

\begin{tabular}{clc}
\hline No. & \multicolumn{1}{c}{ Source } & Mortality Rate $(\%)$ \\
\hline 1. & Leaf & 100 \\
2. & Fruit & 100 \\
3. & Rind & 100 \\
4. & Tapped Rind & 100 \\
5. & Negative Control & 0 \\
\hline
\end{tabular}

\section{CONCLUSION}

The protease activity assay of the crude papain extracts revealed that the greatest activity was observed in an extract from the rind of the papaya conducted through the blending method. Furthermore, the odor test showed that the crude papain extract was best stored $a 0^{\circ} \mathrm{C}$. The protease activity of papain extract reached up to $98 \mathrm{ppm}$. This high protease activity resulted from papain extract that was stored at a temperature of $37^{\circ} \mathrm{C}$. The efficacy test showed that the papain extract was powerful enough to kill Spodoptera litura, especially in wet conditions.

\section{ACKNOWLEDGEMENT}

The authors would like to thank for the support provided by Ministry of Research, Technology and Higher Education Republic of Indonesia, Universitas Indonesia, and USAID SHERA.

\section{REFERENCES}

Abbott, W.S., 1925. A Method of Computing the Effectiveness of an Insecticide. Journal of Economic Entomology, Volume 18(2), pp. 265-267

Ardini, S.P., Ibrahim, M., Trimulyono, G., 2014. Efektivitas Pemberian Getah Pepaya (Carica papaya) pada Tanaman Cabai Merah terhadap Penurunan Serangan Begomovirus (The Effectiveness of Giving Papaya Latex (Carica papaya) on Red Chili Plants to Reduction of Begomovirus Attacks). Jurnal Mahasiswa Teknologi Pendidikan, Volume 3(3), pp. 1982013

Bauer, M.W., Halio, S.B., Kelly, R.M., 1996. Proteases and Glycosyl Hydrolase from Hyperthermophilic Microorganism. Advance in Protein Chemistry, Volume 48, pp. 271310

Djojosumarto, P., 2008. Pestisida dan Aplikasinya (Pesticides and their Applications). Agromedia Pustaka, Jakarta

Haq, S.K., Atif, S.M., Khan, R.H., 2004. Protein Proteinase Inhibitor Genes in Combat against Insects, Pests, and Pathogens: Natural and Engineered Phytoprotection. Archives Biochemistry Biophysics, Volume 431(1), pp. 145-159

Harrison, R.L., Bonning, B.C., 2010. Proteases as Insecticidal Agents. Toxins, Volume 2(5), pp. 935-953

Marwoto, Suharsono, 2008. Strategi dan Komponen Teknologi Pengendalian Ulat Grayak (Spodoptera litura) pada Tanaman Kedelai (Strategy and Component of Armyworn (Spodoptera litura) on Soybean Plants). Jurnal Litbang Pertanian, Volume 27(4), pp. 131136

Mursyahadah, N., Hartani, N., Hendra, M., 2015. Uji Efektifitas Ekstrak Daun Tigaron (Crateva religiosa g. Forst.) terhadap Mortalitas Ulat Grayak (Spodoptera litura F.) (Lepidoptera: Noctuidae) di Laboratorium (Effectiveness Test of Tigaron Leaf Extract (Crateva religiosa $g$ Forst.) on Mortality of Armyworm (Spodoptera litura F.) (Lepidoptera: Noctuidae) in Laboratory). Prosiding Seminar Sains dan Teknologi FMIPA Unmul, Surabaya 
Pechan, T., Ye, L., Chang, Y., Mitra, A., Lin, L., Davis, F.M., Williams, W.P., Luthe, D.S., 2000. A Unique 33-kD Cysteine Proteinase Accumulates in Response to Larval Feeding in Maize Genotypes Resistant to Fall Armyworm and other Lepidoptera. Plant Cell, Volume 12(7), pp. 1031-104

Qiao, Y., Tong, J., Wei, S., Du, X., Tang, X., 2009. Economic Methods of Ginger Protease's Extraction and Purification. In: IFIP International Federation for Information Processing, Volume 295, Computer and Computing Technologies in Agriculture, Volume 3, eds. D. Li, Z. Chunjiang, Springer, Boston, USA, pp. 1619-1628

Syakir, M., Munarso, J., Yusniarti, S., Budiharto, A., 2012. Pestisida Nabati (Vegetable Pesticides). Ministry of Agriculture: Center for Plantation Research and Development

Taufik, Y., 2015. Statistik Produksi Hortikultura (Horticultural Production Statistics). Directorate General of Horticulture, Ministry of Agriculture, Jakarta, Indonesia, pp. 16-20

Weber, G.F., 1973. Bacterial and Fungal Diseases of Plants in the Tropics. University of Florida Press., Gainesville, USA, pp. 372-383 